Original Article

\title{
Food habits of indian crested porcupine (Hystrix indica) (Kerr 1792), in district Bagh, Azad Jammu and Kashmir
}

\author{
Hábitos alimentares do porco-espinho de crista indiano (Hystrix indica) (Kerr 1972) \\ nos distritos de Bagh, Azad Jammu e Caxemira
}

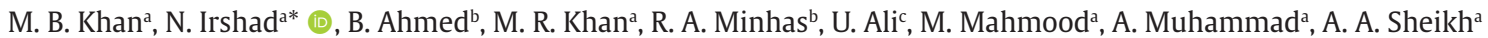 \\ and N. Ashraf ${ }^{b}$
}

aDepartment of Zoology, University of Poonch, Rawalakot, AJ\&K Pakistan

${ }^{b}$ Department of Zoology, University of Azad Jammu and Kashmir Muzaffarabad, AJ\&K Pakistan

'Department of Zoology, Mirpur University of Science and Technology, Mirpur, AJ\&K Pakistan

\begin{abstract}
The Indian Crested Porcupine (Hystrix indica) is classified as an agricultural pest species. It feeds on plants and crops; hence, it is responsible for massive financial losses worldwide. The current study was conducted to assess the diet composition of Indian Crested Porcupine in District Bagh, Azad Jammu and Kashmir (AJ\&K). Thus, fecal samples were collected and examined from different sampling sites. Reference slides of the material collected from the study area were prepared for identification of dietary components in fecal pellets. A total of 80 fecal samples were collected and processed. Percent relative frequencies (P.R.F.) were calculated for each plant species recovered from pellets. Data revealed that Indian Crested Porcupine consumed 31 plant species in its diet, among them Zea mays (34.31 \pm 7.76$)$ was the most frequently selected species followed by Rumex obtusifolius (15.32 \pm 2.57$)$ and Melia azedarach $(12.83 \pm 4.79)$. The study revealed that the greatest diversity of $(n=20)$ plant species were consumed in summer season while minimum $(n=13)$ species were used during winter. Among the parts of plants, stem was highly consumed in spring (57.2\%) as compared to seed in fall (36.7\%) while spikes and leaf were the least recovered parts from the fecal matter. The Berger-Parker diversity index showed highly diversified food (10.92) in the summer time of the year as compared to the autumn season (2.95). This study provides a baseline for the diet preference of this pest in the study area. Based on current findings, a detailed investigation on damage assessment, exploration, habitat use and management of Indian Crested Porcupine in AJ\&K has been recommended.
\end{abstract}

Keywords: porcupine, Hystrix indica, AJ\&K, diet preference, fecal analysis.

\section{Resumo}

O porco-espinho de crista indiano (Hystrix indica) é classificado como uma espécie de praga agrícola. Alimenta-se de plantas e colheitas; portanto, é responsável por enormes perdas financeiras em todo o mundo. 0 estudo atual foi realizado para avaliar a composição da dieta do porco-espinho de crista indiano nos distritos de Bagh, Azad Jammu e Caxemira (AJ\&K). Assim, amostras fecais foram coletadas e examinadas em diferentes locais de amostragem. Lâminas de referência do material coletado na área de estudo foram preparadas para identificação dos componentes da dieta em pellets fecais. Um total de 80 amostras fecais foi coletado e processado. As frequências relativas percentuais (P.R.F.) foram calculadas para cada espécie de planta recuperada de pelotas. Os dados revelaram que o porco-espinho indiano consumiu 31 espécies de plantas em sua dieta, entre elas Zea mays $(34,31 \pm 7,76)$ foi a espécie mais selecionada, seguida por Rumex obtusifolius $(15,32 \pm 2,57)$ e Melia azedarach $(12,83 \pm 4,79)$. 0 estudo revelou que a maior diversidade de $(n=20)$ espécies de plantas foi consumida no verão, enquanto o mínimo $(n=13)$ espécies foi utilizado durante o inverno. Entre as partes das plantas, o caule foi muito consumido na primavera (57,2\%) em relação à semente no outono (36,7\%), enquanto a espiga e a folha foram as partes menos recuperadas da matéria fecal., $O$ índice de diversidade de Berger-Parker mostrou alimentos altamente diversificados (10,92) no verão do ano em comparação com o outono $(2,95)$. Este estudo fornece uma linha de base para a preferência alimentar dessa praga na área de estudo. Com base nas descobertas atuais, uma investigação detalhada sobre avaliação de danos, exploração, uso de habitat e gerenciamento de porco-espinho de crista indiano em AJ\&K foi recomendada. Palavras-chave: porco-espinho, Hystrix indica, AJ\&K, preferência de dieta, análise fecal.

*e-mail: nausheen_irshad@yahoo.com

Received: September 1, 2020 - Accepted: December 6, 2020 


\section{Introduction}

Indian Crested Porcupine ((Hystrix indica) (Kerr 1792), is a commonly found rodent throughout the Pakistan (Mushtaq et al., 2010). It inhabits different types of habitats like plantations, canal sides, and embankments of water bodies. It also prefers to live in subtropical broadleaf hill forests in Asia. Indian Crested Porcupine are herbivorous in diet, feeding upon a variety of plants and crops (Talukdar et al., 2019) and often cause massive losses to orchard owners and farmers by damaging fruits, vegetables and other flowering plants (Khan et al., 2007; Pervez, 2006; Hafeez et al., 2011). The economically important varieties of maize, potato and groundnut were damaged by this species (Khan et al., 2000; Hafeez et al., 2011). Besides, the pumpkin (Cucurbita moschata), okra (Abelmoschus esculentus), onion (Allium cepa) carrot (Daucus carota) and bitter gourd (Momordica charantia) were also reported to be eaten by Indian Crested Porcupine (Pervez, 2006; Hafeez et al., 2011). Some grasses such as Johnson grass (Sorghum halepense), buffelgrass (Cenchrus ciliaris), Sewan grass (Elionurus hirsutus) and oilgrass (Cymbopogon jwarancusa) were also trampled by it (Khan et al., 2000; Hafeez et al., 2011). Despite the significant loss caused by the species, no scientific data are available regarding damage assessment of Indian Crested Porcupine in AJ\&K. Therefore, this is the first study of the foraging behavior and effect of Porcupine as a pest in district Bagh, AJ\&K.

\section{Materials and methods}

\subsection{Study Area}

The area under study is comprised of $1368 \mathrm{~km}^{2}$ and lies at $33^{\circ} 53^{\prime}-34^{\circ} 07^{\prime} \mathrm{N}, 73^{\circ} 29^{\prime}-74^{\circ} 00^{\prime} \mathrm{E}$ with an altitude of $1500 \mathrm{~m}$ to $2500 \mathrm{~m}$ above sea level (Figure 1). Topographically, it is a hilly area covered by the Pir- Panjal range that is sparsely covered with coniferous forests. Generally, the climate of the area change with elevation having a temperature range between $2{ }^{\circ} \mathrm{C}$ to $40{ }^{\circ} \mathrm{C}$. The annual rainfall of the study is about $1500 \mathrm{~mm}$ (Alif, 2016).

\subsection{Method}

The study area was divided into three study sites: Dheerkot (site I), Bagh (site II) and Hari Gehal (site III) (Figure 1). The ten potential sub sites were selected from each site to collect fecal material during a period of one year (November 2015 to October 2016). It covered all four seasons of the year including winter (November-January) spring (February-April); summer (May-August), and autumn (September-October).

\subsection{Sampling}

Food and feeding habits were investigated by analyzing almost 80 fecal samples collected from 30 study sites of the study area. The collected fecal samples were identified through their characteristic size and shape, labeled and stored in refrigerator at $-4^{\circ} \mathrm{C}$.

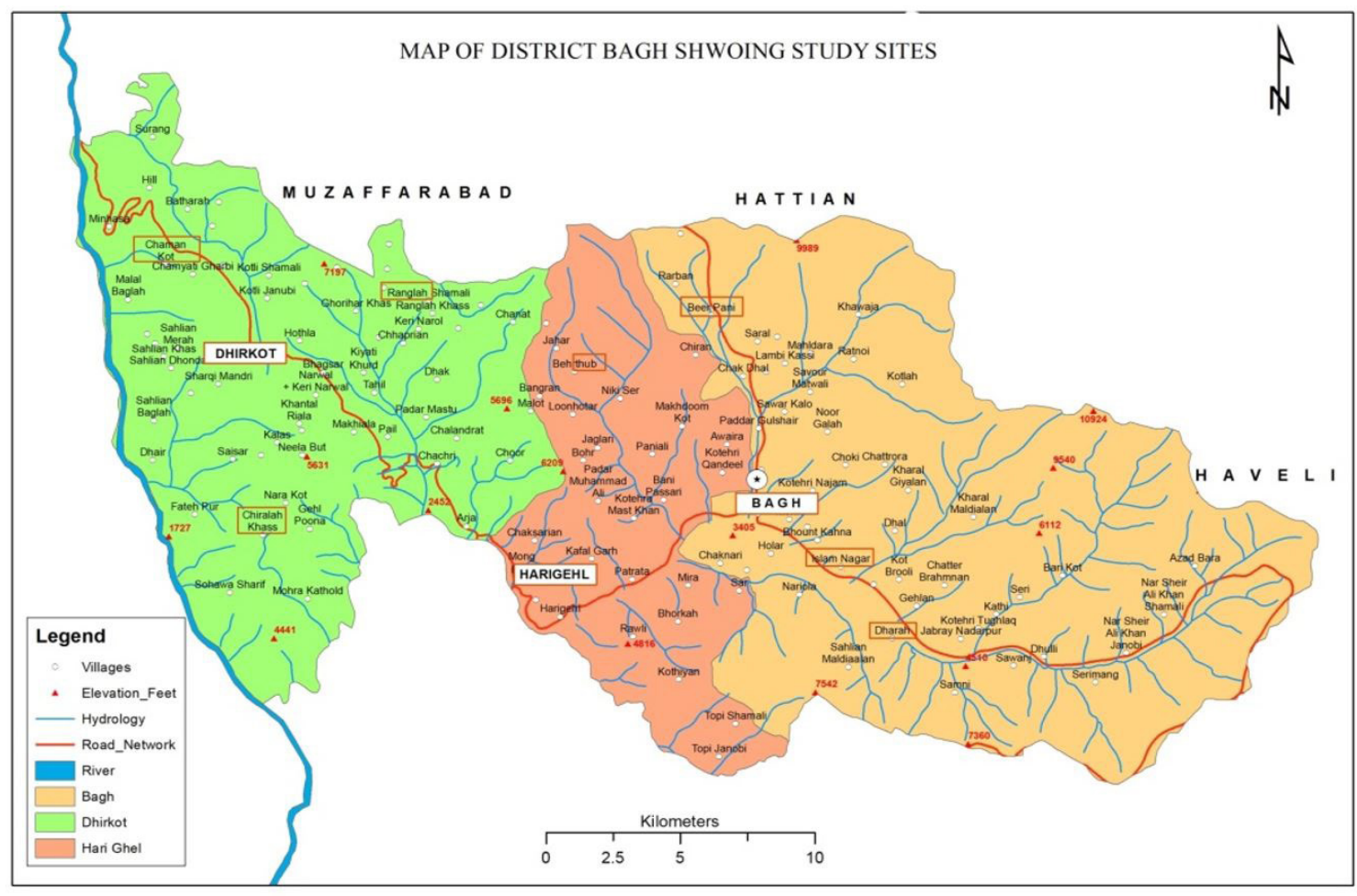

Figure 1. Location map of study area showing different study sites during study period. 


\subsection{Reference Slides}

The main seasonal plants and damage plant of the area under study were used in making reference slides by following the method of Williams (1962) and Ward (1970). The dried vegetation fragments were soaked for a night in a mixture of distilled water, ethyl alcohol, and glycerin (1:1:1) and afterward passed through water for 10-20 minutes. A homogenizer was used to grind the plant tissue (Virtis, Model 302968) in a medium of distilled water. To clear the specimen, the ground tissues were put in a cotton cloth and placed in $1 \%$ sodium hypochlorite. Then it was soaked in 5\% Chlorox (chlorine bleach) and distilled water (1:4) for half an hour. Dilute acetic acid was added to the contents to neutralize the basic effect of sodium hypochlorite. The contents were treated with a mordant solution for 15-30 minutes, and basic residues were removed by dripping the distilled water. For staining, the contents were treated with hematoxylin for 10-15 minutes and then washed with water. A drop of Canada balsam was placed on a clear glass slide. Stained plant material was transferred in mounting medium on a glass slide with the help of a camel hair brush and spread uniformly. Again a couple of drops of Canada balsam were placed on the stained plant material and secured with a coverslip of $22 \times 40 \mathrm{~mm}$.

\subsection{Diet analysis}

During laboratory analysis, the fecal material was washed with water and soaked in distilled water in a cotton cloth. The distilled water was filtered and remains were passed through $70 \%$ alcohol for 10 minutes. To achieve differentiation, the fragments were treated with light green stain. Alcohol gradients (30\%, 40\%, 50\%, 70\%, $90 \%$ and $100 \%$ ) were used to prepare permanent mounts. The different slides prepared were observed under light microscope $(60 \mathrm{X})$ and compared with reference slides. The percent relative frequency of fragments of various species of plants was calculated as:

Percent Relative Frequency $(\%)=\frac{\text { TotalNo. offragments ofa sp. }}{\text { Total No. offragments analysed }} \times 100$

For the diversification of food in dissimilar seasons Berger-Parker index was used as:

Berger-Parker index $d=\frac{N_{\max }}{N}$

Where $N_{\max }$ showed the maximum numeral figure of fragments of a plant species in a season and $\mathrm{N}$ were the overall parts of plants recovered in that season respectively. To calculate the overlap among different study sites, Sorensen's similarity index was implied as:

$$
\text { Sorensen's similarity index }=\frac{2(C)}{A+B} \times 100
$$

Where $C$ was the number of plant species found commonly from both localities A and B. While A and B represent the plant species recovered from locality $A$ and $B$ respectively.

Kruskal-Wallis test was performed to investigate level of significance $(\mathrm{P}<0.05)$ among the diet variation in different study localities and seasons.

\section{Results}

The analysis of fecal samples showed following spatio-temporal diversity in the nutrition of Indian Crested Porcupine in study area:

\subsection{Spatial Food Analysis}

The following diversity of plant species were recovered from three study sites: site I (30), site II (30) and site III (26). Of consumed plants, Zea mays (R.F=16.49\%), Melia azedarach (R.F=8.21\%), Rumex obtusifolius (R.F=6.32\%) and Pinus roxburghii (R.F=5.26\%) were found to be highly used in site I. In site II, Zea mays (R.F=9.26\%), Arisaema jacquemontii (R.F=5.65\%), Pinus wallichiana (R.F=7.28\%), Rumex obtusifolius (R.F=7.69\%) and Diospyros lotus (R.F=5.11\%) were more often selected. While the most used plant species by Indian Crested Porcupine in site III, were Zea mays (R.F=7.47\%), Sorghum halepense (R.F=6.41\%), Melia azedarach (R.F=6.41\%), Brassica campestris (R.F=6.05\%) and Pinus roxburghii (R.F=6.05\%) (Table 1 ). Sorensen's similarity index depicted a high resemblance amongst the study sites I\&II, I\&III (91.80\% each) and II and III (91.22\%).

Different parts (via stems, roots, leaves, seeds spikes, tubers, rhizomes and fruits) of plants were recovered from the fecal material of species. Percent elative frequency showed that the stem and seeds were the most consumed parts while leaves and spikes were the least consumed parts in all sites (Figure 2).

\subsection{Temporal Food Analysis}

Analysis of fecal samples collected in different seasons showed the following diversity in the food of Porcupine.

\subsubsection{Winter}

During winter the 13 plant species were found to be eaten by Indian Crested Porcupine collected in winter season. Among them, Rumex obtusifolius (15.32 \pm 2.57$)$ was

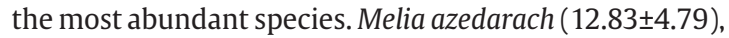
Arisaema jacquemontii (11.46 \pm 1.79 ), and Pinus wallichiana $(9.42 \pm 1.86)$ were recovered in sufficient proportion. While Allium cepa (2.38 \pm 0.82$)$, Asphodelus tenuifolius ( $2.72 \pm 0.98$ ) and Brassica campestris (1.82 \pm 1.41$)$ were least selected species. A quantifiable amount of polythene bags and pieces of clothes $(5.45 \pm 0.94)$ were also recovered from

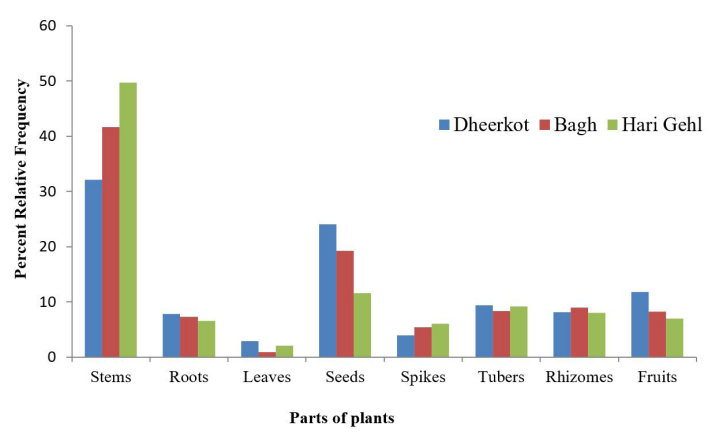

Figure 2. Percent relative frequency of different parts of plants recovered from the fecal samples collected from the study area. 
the fecal pellets. A small proportion $(4.77 \pm 0.63)$ could not be identified (Table 2). Among the different parts of plants being consumed the stem was used up mostly accounting about $41.3 \%$ of the total, followed by fruit (17.8\%), rhizome (15.5\%), seed (13.8\%) and tuber $(0.73 \%)$. While in winter season leaf and spike were not consumed by species (Figure 3 ).

\subsubsection{Spring}

During spring 16 plant species were extracted. Amongst these Triticum aestivum (13.28 \pm 1.90$)$, Melia azedarach (11.83 \pm 1.84$)$, and Brassica campestris (11.05 \pm 1.10$)$ were

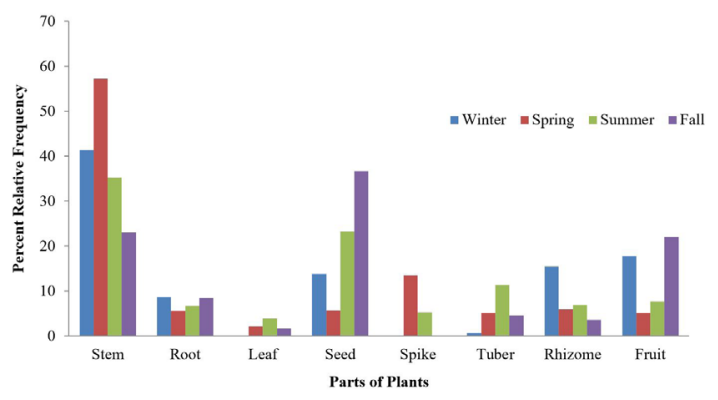

Figure 3. Seasonal variation in the percentage of different parts of plant recovered from fecal samples in the study area.

Table 1. Percent relative frequency of plant species recovered from the fecal sample of Indian Crested Porcupine collected from the three study sites of study area.

\begin{tabular}{|c|c|c|c|c|}
\hline \multirow{2}{*}{ Scientific Name } & \multirow{2}{*}{ Common Name } & \multicolumn{3}{|c|}{ Percent Relative Frequency } \\
\hline & & Site 1(Dheerkot) & Site 11(Bagh) & Site 111 (Hari Gehal) \\
\hline Allium cepa & Onion & 0.63 & 0.82 & 0.00 \\
\hline Amaranthus viridis & Green amaranth & 2.32 & 1.16 & 2.49 \\
\hline Arisaema jacquemontii & Blume & 5.12 & 5.65 & 5.34 \\
\hline Asphodelus tenuifolius & Onion weed & 0.84 & 0.82 & 0.00 \\
\hline Brassica campestris & Mustard & 2.74 & 4.63 & 6.05 \\
\hline Capsicum annuum & Pepper & 1.54 & 0.14 & 0.00 \\
\hline Cucumis melo & Musk melon & 1.68 & 4.22 & 3.56 \\
\hline Cyperus rotundus & Nut grass & 3.16 & 1.91 & 3.02 \\
\hline Diospyros lotus & Date Plum & 1.75 & 5.11 & 0.71 \\
\hline Eucalyptus camaldulensis & Red gum & 4.14 & 3.74 & 3.20 \\
\hline Ficus carica & Common fig & 0.91 & 1.43 & 3.20 \\
\hline Gladiolus dalenii & Sword lily & 3.79 & 2.79 & 2.67 \\
\hline Hordeum vulgare & Barley & 1.19 & 1.09 & 1.78 \\
\hline Lagenaria siceraria & calabash & 2.04 & 1.36 & 2.85 \\
\hline Lycopersicum esculentum & Tomato & 2.88 & 2.04 & 2.85 \\
\hline Melia azedarach & Chinaberry tree & 8.21 & 7.49 & 6.41 \\
\hline Morus alba & Mulberry & 1.12 & 0.48 & 1.07 \\
\hline Olea cuspidata & Wild olive & 0.98 & 1.36 & 0.00 \\
\hline Pinus roxburghii & Indian pine & 5.26 & 6.33 & 6.05 \\
\hline Pinus wallichiana & Blue pine & 4.98 & 7.28 & 5.34 \\
\hline Pisum sativum & Garden pea & 0.98 & 0.14 & 2.85 \\
\hline Prosopis juliflora & Mesquite & 0.28 & 1.09 & 0.00 \\
\hline Prunus padus & Bird cherry & 1.82 & 1.02 & 1.60 \\
\hline Rumex obtusifolius & Broad-leaved dock & 6.32 & 7.69 & 6.05 \\
\hline Solanum melongena & Brinjal & 0.21 & 0.88 & 0.71 \\
\hline Solanum tuberosum & Potato & 2.32 & 1.16 & 3.91 \\
\hline Sorghum halepense & Johnson grass & 4.56 & 4.70 & 6.41 \\
\hline Triticum aestivum & Common wheat & 3.02 & 4.22 & 2.49 \\
\hline Tulipa humilis & Tulip & 0.00 & 0.00 & 2.21 \\
\hline Vitex negundo & Chinese chaste tree & 0.28 & 0.61 & 0.36 \\
\hline Zea mays & Maize & 16.49 & 9.26 & 7.47 \\
\hline Others & & 3.72 & 3.95 & 5.69 \\
\hline Unidentified Material & & 4.14 & 4.83 & 3.56 \\
\hline
\end{tabular}


the most consumed species. Pinus roxburghii (7.59 \pm 1.77 ), Rumex obtusifolius (5.80 \pm 1.72$)$ and Solanum tuberosum $(5.80 \pm 1.60)$ were recovered in sufficient proportion. While other plants like Prosopis juliflora $(2.23 \pm 1.83)$, Vitex negundo (1.67 \pm 1.26$)$, Arisaema jacquemontii $(1.23 \pm 0.96)$ were least noted in this season (Table 2). Among different parts of plant stems were more utilized (57.2\%), part over spike (13.4\%) while rhizome (5.95) and leaves were detected in small (2.09\%) proportions (Figure 3).

\subsubsection{Summer}

During summer almost 20 plant species were found to be present in feces. The plants of Zea mays (9.16 \pm 1.86$)$, Cucumis melo (9.16 \pm 1.76$)$ and Gladiolus dalenii, $(8.40 \pm 1.90)$ were the most widely consumed species. Ficus carica

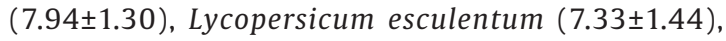
Cyperus rotundus $(5.04 \pm 0.75)$ and Solanum tuberosum (4.89 \pm 0.78$)$ were recovered in sufficient proportion. Pinus wallichiana (2.14 \pm 0.52$)$, Melia azedarach $(1.37 \pm 0.50)$ and

Table 2. Percent relative frequency of different plant species recovered from fecal samples of Indian Crested Porcupine in different seasons.

\begin{tabular}{|c|c|c|c|c|c|}
\hline Scientific Name & Common Names & Winter (PRF) & Spring (PRF) & $\begin{array}{c}\text { Summer } \\
\text { (PRF) }\end{array}$ & Fall (PRF) \\
\hline Allium сера & Onion & $2.38 \pm 0.82$ & $0.00 \pm 0.00$ & $0.00 \pm 0.00$ & $0.00 \pm 0.00$ \\
\hline Amaranthus viridis & Green amaranth & $0.00 \pm 0.00$ & $0.00 \pm 0.00$ & $3.05 \pm 0.67$ & $4.23 \pm 1.32$ \\
\hline Arisaema jacquemontii & Blume & $11.46 \pm 1.79$ & $1.23 \pm 0.96$ & $4.58 \pm 1.50$ & $4.02 \pm 1.51$ \\
\hline Asphodelus tenuifolius & Onion weed & $2.72 \pm 0.98$ & $0.00 \pm 0.00$ & $0.00 \pm 0.00$ & $0.00 \pm 0.00$ \\
\hline Brassica campestris & Mustard & $1.82 \pm 1.41$ & $11.05 \pm 1.10$ & $3.97 \pm 0.78$ & $0.00 \pm 0.00$ \\
\hline Capsicum annuum & Pepper & $0.00 \pm 0.00$ & $0.00 \pm 0.00$ & $0.00 \pm 0.00$ & $2.41 \pm 1.07$ \\
\hline Cucumis melo & Musk melon & $0.00 \pm 0.00$ & $2.68 \pm 0.98$ & $9.16 \pm 1.76$ & $2.62 \pm 1.86$ \\
\hline Cyperus rotundus & Nut grass & $2.95 \pm 1.38$ & $0.00 \pm 0.00$ & $5.04 \pm 0.75$ & $3.02 \pm 1.80$ \\
\hline Diospyros lotus & Date Plum & $8.97 \pm 2.94$ & $2.79 \pm 0.83$ & $0.00 \pm 0.00$ & $0.00 \pm 0.00$ \\
\hline Eucalyptus camaldulensis & Red gum & $3.75 \pm 0.95$ & $3.79 \pm 0.94$ & $1.07 \pm 0.50$ & $1.91 \pm 1.60$ \\
\hline Ficus carica & Common fig & $0.00 \pm 0.00$ & $0.00 \pm 0.00$ & $7.94 \pm 1.30$ & $0.00 \pm 0.00$ \\
\hline Gladiolus dalenii & Sword lily & $2.84 \pm 1.13$ & $0.00 \pm 0.00$ & $8.40 \pm 1.90$ & $2.82 \pm 1.73$ \\
\hline Hordeum vulgare & Barley & $0.00 \pm 0.00$ & $4.80 \pm 1.60$ & $0.00 \pm 0.00$ & $0.00 \pm 0.00$ \\
\hline Lagenaria siceraria & Calabash & $0.00 \pm 0.00$ & $0.00 \pm 0.00$ & $4.58 \pm 1.22$ & $2.92 \pm 1.06$ \\
\hline Lycopersicum esculentum & Tomato & $0.00 \pm 0.00$ & $0.00 \pm 0.00$ & $7.33 \pm 1.44$ & $2.72 \pm 1.06$ \\
\hline Melia azedarach & Chinaberry tree & $12.83 \pm 4.79$ & $11.83 \pm 1.84$ & $1.37 \pm 0.50$ & $5.13 \pm 2.01$ \\
\hline Morus alba & Mulberry & $0.00 \pm 0.00$ & $0.00 \pm 0.00$ & $3.36 \pm 0.71$ & $2.31 \pm 1.47$ \\
\hline Olea cuspidata & Wild olive & $0.00 \pm 0.00$ & $0.00 \pm 0.00$ & $0.00 \pm 0.00$ & $4.02 \pm 2.00$ \\
\hline Pinus roxburghii & Indian pine & $9.19 \pm 2.15$ & $7.59 \pm 1.77$ & $2.60 \pm 0.60$ & $3.82 \pm 0.94$ \\
\hline Pinus wallichiana & Blue pine & $9.42 \pm 1.86$ & $8.26 \pm 2.40$ & $2.14 \pm 0.52$ & $3.82 \pm 0.72$ \\
\hline Pisum sativum & Garden pea & $0.00 \pm 0.00$ & $0.00 \pm 0.00$ & $4.89 \pm 1.31$ & $0.00 \pm 0.00$ \\
\hline Prosopis juliflora & Mesquite & $0.00 \pm 0.00$ & $2.23 \pm 1.83$ & $0.00 \pm 0.00$ & $0.00 \pm 0.00$ \\
\hline Prunus padus & Bird cherry & $0.00 \pm 0.00$ & $0.00 \pm 0.00$ & $0.00 \pm 0.00$ & $4.63 \pm 2.71$ \\
\hline Rumex obtusifolius & Broad-leaved dock & $15.32 \pm 2.57$ & $5.80 \pm 1.72$ & $2.90 \pm 0.76$ & $3.82 \pm 1.57$ \\
\hline Solanum melongena & Brinjal & $0.00 \pm 0.00$ & $0.00 \pm 0.00$ & $3.05 \pm 0.82$ & $0.00 \pm 0.00$ \\
\hline Solanum tuberosum & Potato & $0.00 \pm 0.00$ & $5.80 \pm 1.60$ & $4.89 \pm 0.78$ & $0.00 \pm 0.00$ \\
\hline Sorghum halepense & Johnson grass & $6.13 \pm 0.94$ & $3.46 \pm 1.96$ & $4.43 \pm 0.99$ & $5.73 \pm 1.76$ \\
\hline Triticum aestivum & Common wheat & $0.00 \pm 0.00$ & $13.28 \pm 1.90$ & $0.00 \pm 0.00$ & $0.00 \pm 0.00$ \\
\hline Tulipa humilis & Tulip & $0.00 \pm 0.00$ & $3.35 \pm 1.80$ & $0.00 \pm 0.00$ & $0.00 \pm 0.00$ \\
\hline Vitex negundo & Chinese chaste tree & $0.00 \pm 0.00$ & $1.67 \pm 1.26$ & $0.00 \pm 0.00$ & $0.00 \pm 0.00$ \\
\hline Zea mays & Maize & $0.00 \pm 0.00$ & $0.00 \pm 0.00$ & $9.16 \pm 1.86$ & $34.31 \pm 7.76$ \\
\hline Others & & $5.45 \pm 0.94$ & $4.91 \pm 0.94$ & $3.21 \pm 0.74$ & $2.92 \pm 0.99$ \\
\hline Unidentified Material & & $4.77 \pm 0.63$ & $5.47 \pm 0.51$ & $2.90 \pm 0.74$ & $4.02 \pm 1.37$ \\
\hline
\end{tabular}


Eucalyptus camaldulensis $(1.07 \pm 0.50)$ were present in least proportions. A significant amount of unidentified materials (2.90 \pm 0.74$)$ were also found (Table 2$)$. Moreover, the stem parts (35.2\%), seeds (23.2\%) and tubers (11.3\%) constituted a higher percentage of diet than spikes (5.22\%) and leaves of the plants (3.85) (Figure 3).

\subsubsection{Fall}

Among the 18 plant species consumed by the Indian Crested Porcupine during fall season, Zea mays (34.31 \pm 7.76 ) was the most preferred plant species. The other plant species like Sorghum halepense (5.73 \pm 1.76$)$, Melia azedarach (5.13 \pm 2.01$)$, and Prunus padus $(4.63 \pm 2.71)$ were also recovered in sufficient amounts. The least consumed plants

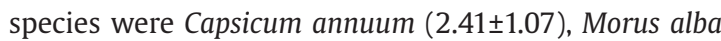
(2.31 \pm 1.47$)$ and Eucalyptus camaldulensis (1.91 \pm 1.60$)$.The occurrence of other and unidentified material found from the fecal sample collected in autumn season were $2.92 \pm 0.99$ and $4.02 \pm 1.37$ respectively (Table 2 ). The most preferred parts of the plant in fall season were seed (36.7\%) followed by stem (23\%), fruit (22\%) and leaf (1.72\%) (Figure 3 ).

The variation in diet of species during different seasons was evaluated by Berger-Parker diversity index which revealed that the diet of Indian Crested Porcupine varied mostly (10.92) in summer, followed by spring (7.53), winter (6.53) and fall (2.95) (Table 3). There was a nonsignificant difference in the relative frequencies of plant species consumed by the porcupines during different seasons (Kruskal-Wallis test: $\mathrm{X}^{2}=0.40, \mathrm{p}=0.750, \mathrm{df}=3$ ) and among different localities (Kruskal-Wallis test: $\mathrm{X}^{2}=0.08$, $\mathrm{p}=0.922, \mathrm{df}=2$ ) (Table 4$)$.

\section{Discussion}

Porcupine management and diet preference has been well studied in Pakistan (Ahmad et al., 2003; Awan et al., 2004; Pervez, 2006; Khan et al., 2007; Mian et al., 2007; Hafeez et al., 2011; Hafeez et al., 2014; Khan et al., 2014; Hafeez et al., 2015; Pervez et al., 2015). However, the current analysis is the first case study of damage imparted by Indian Crested Porcupine on plants and crops in least studied region of AJK (district Bagh).

During investigation 31 important plant species were documented from feces of Indian Crested Porcupine. These are categorized as vegetables (8), fruits (6), trees (5), cereal grains (3), herbs (3) shrubs (2) grasses (2) and flowering plants (2). Among vegetables, onion (Allium cepa), chili pepper (Capsicum annuum), brinjal (Solanum melongena), calabash (Lagenaria siceraria), potato (Solanum tuberosum), pea (Pisum sativum), tomato (Lycopersicum esculentum) and mustard plant (Brassica campestris) were consumed. Whereas the fruits included date plum (Diospyros lotus), wild olive (Olea cuspidata), mulberry (Morus alba), common fig (Ficus carica) and musk melon (Cucumis melo). The cereal grains wheat (Triticum aestivum), maize (Zea mays) and barley (Hordeum vulgare)) were also fed upon by Indian Crested Porcupine. The cereal grains are a vital source of food worldwide. The current study region is a rural area of a developing country, where people's livelihood is mainly dependent on agriculture, therefore, the crops and livestock are being considered as major household income sources. Hence, human-Porcupine conflict is an increasingly important issue.

On average, consumption of plants species at three different sites of study area was similar with Zea mays, Melia azedarach, Pinus roxburghii and Rumex obtusifolius

Table 3. Berger-Parker diversity index of diversity in seasonal sample of the fecal pellets of the Indian Crested Porcupine in Bagh, AJ\&K.

\begin{tabular}{ccccc}
\hline Season & $\begin{array}{c}\text { Number of food } \\
\text { particles }(\boldsymbol{N})\end{array}$ & $\begin{array}{c}\text { Maximum number of food } \\
\text { particles }\left(\boldsymbol{N}_{\max }\right)\end{array}$ & Berger-Parker index $\left(\frac{\boldsymbol{N}_{\max }}{\boldsymbol{N}}\right)$ & $\mathbf{1} / \mathbf{d}$ \\
\hline Winter & 881 & 135 & 0.15323 & 6.53 \\
Spring & 896 & 119 & 0.13281 & 7.53 \\
Summer & 655 & 60 & 0.09160 & 10.92 \\
Fall & 1006 & 341 & 0.33897 & 2.95 \\
\hline
\end{tabular}

Table 4. Kruskal-Wallis test for spatial and seasonal diet variation of Indian Crested Porcupine in the study area during study period.

\begin{tabular}{cccccc}
\hline Localities & DF & SS & MS & F & P \\
\hline Between & $\mathbf{2}$ & 136.2 & 68.114 & 0.08 & 0.9222 \\
Within & 96 & 80672.8 & 840.341 & & 0.7502 \\
Total & 98 & 80809.0 & & 0.40 & \\
Between & $\mathbf{3}$ & Seasons & 551.31 & & \\
Within & 128 & 1654 & 1363.77 & & \\
Total & 131 & 176217 & & & \\
\hline
\end{tabular}


found to be highly consumed by Indian Crested Porcupine. The area is sparsely covered with coniferous forests and has similar types of hilly habitats and vegetation. Besides, Indian Crested Porcupine is strictly herbivore in diet (Talukdar et al., 2019), therefore a high overlap (Sorensen's similarity index) in food items was noted in the diet of animal species among different study sites. However, seasonal variation in the diet of Indian Crested Porcupine has been noted in present study. Triticum aestivum (13.28 \pm 1.90$)$, Melia azedarach (11.83 \pm 1.84$)$, and Brassica compestris (11.05 \pm 1.10 ) were recorded as most abundant species in fecal samples collected during spring season. This is in accordance of findings of Hafeez et al. (2014), who found that the Triticum aestivum $(20.45 \pm 1.20)$ as major consumed crop along with some other plants like Prosopis

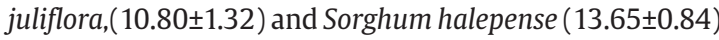
in the diet of Indian Crested Porcupine consumed in spring in rain bestowed Pothwar Plateau, Punjab, Pakistan.

Zea mays (9.16 \pm 1.86$)$, Cucumis melo $(9.16 \pm 1.76)$ and Gladiolus dalenii $(8.40 \pm 1.90)$ were the most extensively consumed items in summer season. Hafeez et al. (2014) reported Zea mays (16.98 \pm 1.58$)$, Prosopis juliflora

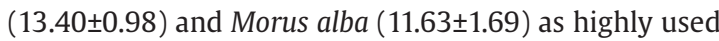
dietary species of Indian Crested Porcupine during summer season from Thal Desert of Pakistan. The present study revealed the least consumption of Eucalyptus camaldulensis, Solanum sp. and Cyperus rotundus in summer diet of Indian Crested Porcupine, similar to the results of Hafeez et al. (2014). Brooks et al. (1988) reported the crops like maize and potato in food of the species in irrigated plains and mountainous areas. Khan et al. (2000) found the species feeding on the grasses like Cenchrus ciliaris and Sorghum halepense at Karluwala (Bhakkar) Pakistan.

Among crops, Zea mays (34.31 17.76 ) was the most used plant species in fall season. In a research conducted in Pothwar Plateau of district Punjab, Pakistan, Hafeez et al. (2015) testified the occurrence of Zea mays (13.91\%), Sorghum vulgaris (13.28\%) and Cynodon dactylon (12.38\%) in the autumn diet of the animal., Moreover, Mian et al. (2007) also expressed in his findings the existence of Zea mays, Hordeum vulgare and Triticum aestivum in the diet of this species in central Punjab, Pakistan. In a study conducted in the Thal Desert, different species of plants like Morus alba (12.32 \pm 0.67 ), Prosopis juliflora (12.20 \pm 1.30$)$, Melia azedarach (12.19 \pm 0.99$)$, Eucalyptus camaldulensis (8.98 \pm 0.90$)$, Zea mays (8.60 \pm 2.02$)$, Sorghum halepense (5.54 \pm 0.64$)$, Cyperus rotundus $(4.44 \pm 1.36)$, Cucumis melo (3.95 \pm 0.50$)$, Dalbergia sissoo ( $3.70 \pm 0.78)$, and Solanumnigrum $(2.93 \pm 0.30$ ) were reported by Hafeez et al. (2014) in the fall diets of this species.

The cultivated plants are noted as major diet components in Punjab (Mian et al., 2007; Hafeez et al., 2011; Khan et al., 2014; Hafeez et al., 2015), in contrast to the present study that has a mixture of wild (15) and cultivated species (16). This could be due to reduced extent of agriculture near our study area compared with the Punjab area. Moreover, similar plants were found to be consumed by Indian Crested Porcupine in district Bagh as reported in existing literature of its feeding habits in Pakistan. But the ranks of consumed plants varied according to season and locality.
The difference of general habitat and abundance of plant species in both areas likely accounts for this variation.

Our work revealed that the stem was the most highly part of the plant eaten by Indian Crested Porcupine. Maximum consumption of stem (29.0\%) was also reported by Hafeez et al. (2011) from fecal pellets of Indian Crested Porcupine from Faisalabad, Pakistan. The greater use of stem could be a gnawing strategy, which was used to sharpen incisors and keep them fit for cutting (Downs et al., 2015). Further stem selection could also lower the effort of the animal required in exploring, digging out and extracting the concealed parts of plants lying beneath the ground surface. (Lovari et al., 2017). The seed was the second frequent plant part found in fecal material., Seed could be a good source of energy, as they have clumped distribution and persistence in autumn, making them a good choice to be eaten by a herbivore. Underground parts of plants are noted as dietary items during different seasons in the current analysis. Even Indian Crested Porcupine can consume them in a food deficient period. Moreover, roots, rhizomes and tubers are high carbohydrate sources (Alkon and Saltz, 1985; Lovari et al., 2017). Mori et al. (2017) explained the presence of roots and tuber in the dietary components of the Indian Crested Porcupine throughout the year in Turkey and central Italy respectively. Leaves were least recovered, perhaps their high digestibility is the reason for such rarity. Akram et al. (2017) reported bark as the major (34.89\%) dietary components of the species in the winter season, followed by twigs (17.18\%), seeds (17.06\%); roots (2.59\%) were a minor part of diet in Madhya Pradesh, India. Wild fruits were noted as the main food source during the winter season in Italy (Mori et al., 2017). Overall diet of Indian Crested Porcupine consists of mainly woody parts of plants in the winter season (Talukdar et al., 2019). Food selection of this species is based on palatability, digestibility, crude contents and availability of food items. This selection is a significant influence that explains how this animal adapts itself in a wide range of habitat (Alkon and Saltz, 1988; Refinetti, 2008; Fattorini and Pokheral, 2012).

Indian Crested Porcupine were noted to feed on 31 wild and cultivated plants in our area, Zea mays the chief crop is most selected diet item of this species. There is an increasing risk of Indian Crested Porcupine as an agricultural pest in this area due to a lack of baseline data regarding feeding habits. A detailed study is required to evaluate the damage of this pest species in cultivated lands of the country.

\section{Acknowledgements}

Authors are indebted to the local community for their support during field surveys and data collection.

\section{References}

AHMAD, M.S., PERVEZ, A. and KHAN, A.A., 2003. Deterioration impact and evaluation of control method of Indian Crested Porcupine (Hystrix indica) on rangeland in Sindh, Pakistan. Journal of Natural History and Wildlife, vol. 1, no. 2, pp. 19-23. 
AKRAM, F., ILYAS, O. and HALEEM, A., 2017. Food and feeding habits of Indian Crested Porcupine in Pench Tiger Reserve, Madhya Pardesh, India. Ambient Science, vol. 4, no. 1, pp. 1-4. http:// dx.doi.org/10.21276/ambi.2017.04.1.ra02.

ALIF, A. 2016 [viewed 06 August 2018]. Azad Jammu and Kashmir District Education Ranking [online]. Available from: www. alifailaan.pk.district-education-rankings

ALKON, P.U. and SALTZ, D., 1985. Potatoes and the nutritional ecology of crested Porcupine in a desert biome. Journal of Applied Ecology, vol. 22, no. 3, pp. 727-737. http://dx.doi.org/10.2307/2403225.

ALKON, P.U. and SALTZ, D., 1988. Influence of season and moonlight on temporal activity patterns of Indian Crested Porcupines (Hystrix indica).Journal of Mammalogy, vol. 69, no. 1, pp. 71-80. http://dx.doi.org/10.2307/1381749.

AWAN, M.S., MINHAS, R.A., AHMAD, K.B. and DAR, N.I., 2004. Distribution, food and habitat preferences of small mammals in Machiara National Park, District Muzaffarabad, Azad Kashmir, Pakistan. Punjab University Journal of Zoology, vol. 19, pp. 17-31.

BROOKS, J.E., AHMAD, E. and HUSSAIN, I., 1988. Characteristics of damage by vertebrate pests to groundnuts in Pakistan. Proceedings of the Vertebrate Pest Conference, vol. 13, pp. 129-133.

DOWNS, C.T., PILLAY, K.R., WILSON, A.L. and RAMESH, T., 2015. Digestive parameters and energy assimilation of Cape Porcupine on economically important crops. African Journal of Zoology, vol. 50, no. 4, pp. 307-312.

FATTORINI, N. and POKHERAL, C.P., 2012. Activity and habitat selection of the Indian crested Porcupine. Ethology Ecology and Evolution, vol. 24, no. 4, pp. 377-387. http://dx.doi.org/10 $.1080 / 03949370.2012 .705330$.

HAFEEZ, S., KHAN, A.A., GUL, S., NAWAZ, M.F. and MALIK, A.A., 2014 Determining the food habits of Indian Crested Porcupine (Hystrix Indica) in Thal desert lands of Punjab, Pakistan. University of Agriculture, Faisalabad, Pakistan. The Journal of Biological Sciences, vol. 4, pp. 253-259.

HAFEEZ, S., KHAN, G.S., ASHFAQ, M. and KHAN, Z.H., 2011. Food habits of Indian Crested Porcupine (Hystrix indica) in Faisalabad, Pakistan. Pakistan Journal of Agricultural Sciences, vol. 48, no. 3, pp. 205-210.

HAFEEZ, S., ANJUM, K., KHAN, T.H. and MANZOOR, S., 2015. Food habits of Indian Crested Porcupine (Hystrix indica) in rain fed Pothowar Plateau, Punjab. Pakistan Journal of Agricultural Research, vol. 53, no. 4, pp. 565-579.

KHAN, A.A., MIAN, A. and HUSSAIN, R., 2007. Pictorial guide of Porcupine (Hystrix indica) damage to trees and crops in Pakistan. ALP project on Porcupine biology and management in central Punjab. Islamabad: Pakistan Agricultural Research Council, $44 \mathrm{p}$.

KHAN, A.A., MIAN, A. and HUSSAIN, R., 2014. Deterioration impact of Indian Crested Porcupine, Hystrix indica, on irrigated forest plantations in Punjab, Pakistan. Pakistan Journal of Zoology, vol. 46, no. 6, pp. 1691-1696.
KHAN, A.A., AHMAD, S., HUSSAIN, I. and MUNIR, S., 2000. Deterioration impact of Indian Crested Porcupine, Hytrix indica, on forestry and agricultural systems in Pakistan. International Biodeterioration \&'Biodegradation, vol. 45, no. 3-4, pp. 143-149. http://dx.doi.org/10.1016/S0964-8305(00)00046-9.

LOVARI, S., CORSINI, M.T., GUAZZINI, B., ROMEO, G. and MORI, M., 2017. Suburban ecology of the crested Porcupine in a heavily poached area: a global approach. European Journal of Wildlife Research, vol. 63, no. 1, pp. 10. http://dx.doi.org/10.1007/ s10344-016-1075-0.

MIAN, A., KHAN, A.A., and HUSSAIN, R., 2007. Biology and management of Porcupine, Hystrix indica, in central Punjab, Pakistan. Final Progress Report (2006-2007). Rawalpindi: ALP project, Department of Zoology, University of Arid Agriculture, $129 \mathrm{p}$.

MOHAMMAD, W.F., 2011. The Crested Porcupine Hystrix cristata (Linnaeous 1758) Misurata, Libya. Journal of Ecology and the Natural Environment, vol. 3, no. 7, pp. 9-12.

MORI, E., BOZZI, R. and LAURENZI, A., 2017. Feeding habits of Indian Crested Porcupine in a Mediterranean area of Central Italy. European Journal of Zoology, vol. 84, no. 1, pp. 261-265. http:// dx.doi.org/10.1080/24750263.2017.1329358.

MUSHTAQ, M.A., MIAN, I., HUSSAIN, S., MUNIR, S. and KHAN, A.A., 2010. Evaluation of fresh food baits for the management of Indian Crested Porcupine, Hystrix indica Kerr (Rodentia: hystricidae). Pakistan Journal of Zoology, vol. 42, no. 5, pp. 507-513.

PERVEZ, A. 2006. Developmental biology, feeding patterns and management strategy against Indian Crested Porcupine (Hystrix indica) in Sindh and Baluchistan provinces. In: ALP PROJECT, 3rd Annual Progress Report (2005-2007). Karachi: VPCI/SARC/PARC, 56 pp.

PERVEZ, A., SYED, A.M., AKHLAQ A. and QAZI, A.M., 2015. Evaluation of different food grains as baits for management of Hystrix indica. Pakistan Journal of Agricultural Research, vol. 3, pp. 272-280.

REFINETTI, R., 2008. The diversity of temporal niches in mammals. Biological Rhythm Research, vol. 39, no. 3, pp. 173-192.

TALUKDAR, N.R., CHOUDHURY, P. and SINGH, B., 2019. Current records of Porcupine in northeast India: distribution, habitat preference and conservation. Tropical Ecology, vol. 60, no. 1, pp. 41-51. http://dx.doi.org/10.1007/s42965-019-00005-4.

WARD, A.L. 1970. Stomach content and fecal analysis: methods of forage identification. In: Range and wildlife habitat evaluationa research symposium. Washington, DC: Department of Agriculture, Forest Service, pp. 146-15, Series Miscellaneous publication, no. 1147.

WILLIAMS, O., 1962. The techniques for studying microtine food habits. Journal of Mammalogy, vol. 43, no. 3, pp. 365-368. http:// dx.doi.org/10.2307/1376945. 